\title{
INTRODUCTION
}

\section{Trophodynamics in marine ecology: 70 years after Lindeman}

\author{
Simone Libralato ${ }^{1, *}$, Fabio Pranovi ${ }^{2}$, Konstantinos I. Stergiou ${ }^{3,4}$, Jason S. Link ${ }^{5}$ \\ ${ }^{1}$ Section Oceanography, OGS (Istituto Nazionale di Oceanografia e di Geofisica Sperimentale), Dept. Oceanography, \\ Borgo Grotta Gigante 42/c, 34010 Sgonico (TS), Italy \\ ${ }^{2}$ Department of Environmental Sciences, Informatics and Statistics. University Ca' Foscari, Venice, Castello 2737/b, \\ 30122 Venice, Italy \\ ${ }^{3}$ Laboratory of Ichthyology, Department of Zoology, School of Biology, Aristotle University of Thessaloniki, BOX 134, \\ 54124 Thessaloniki, Greece \\ ${ }^{4}$ Institute of Marine Biological Resources and Inland Waters, Hellenic Centre for Marine Research, Aghios Kosmas, \\ 16604 Athens, Greece \\ ${ }^{5}$ National Oceanic and Atmospheric Administration, National Marine Fisheries Service, 166 Water St., Woods Hole, \\ MA 02543, USA
}

\begin{abstract}
The seminal work of Lindeman (1942), 'The trophic-dynamic aspect of ecology' (Ecology 23:399), has been an important starting point for the holistic view of ecosystem trophodynamics, but it was initially seldom applied to marine ecosystems. Over the past 70 years, research on marine trophodynamics has become more widespread, producing a variety of analytical methods, and increasing our understanding of marine ecosystem functioning. Yet difficulties remain in transforming this body of knowledge into operational management of marine ecosystems and marine resources. This Theme Section on 'Trophodynamics in marine ecology' documents recent advances and lessons learned over the past 70 years, and provides an opportunity to reflect on future directions for marine research.
\end{abstract}

KEY WORDS: Trophodynamics · Food webs $\cdot$ Food chains $\cdot$ Ecosystem indicators $\cdot$ Trophic level Food web models

Resale or republication not permitted without written consent of the publisher

\section{BRIEF HISTORY}

Trophodynamics, by regulating the cycling of mass, energy and nutrients, determines how marine ecosystems function and respond to both internal and external pressures, as food web pathways adapt to facilitate ecosystem resilience and persistence. The first reference to the term 'food chain' was in 1718, and the first graphical depiction of a food web was attempted by Camerano (1880; c.f. Egerton 2007; Table 1). The pioneer of the food chain concept was Elton (1927) in his now classic book 'Animal ecology'. With Lindeman's (1942) classic paper 'Trophic-dynamic aspect of ecology', however, researchers really began to explore and understand the dynamics of ecosystem processes and functioning (Mann 1969; but see also Egerton 2007 and references therein). Lindeman (1942), in fact, examined ecosystem energetics as an integrated whole, positing the concept of trophodynamics, from whence food web thinking advanced (Fig. 1). Later, Clarke (1946) described a marine food web and Hairston et al. (1960) built on Lindeman's work by examining how populations of plants, herbivores and carnivores are regulated at distinct trophic levels.

Successively, trophodynamic concepts have been applied to link changes in primary production to commercial fish production (Ryther 1969, Vollen- 
Table 1. Seminal publications on trophodynamics, extracted from an advanced search on Google Scholar (http://scholar. google.it/; search conducted on 15 August 2014) for books and articles containing at least one of the following terms: 'food web(s)', 'food chain(s)', 'food-chain(s)', 'trophodynamic(s)', 'trophic dynamics', 'trophic-dynamics', 'trophic level(s)', 'trophic pyra$\operatorname{mid}(\mathbf{s})^{\prime}$, 'ecological pyramid(s)', 'pyramids of numbers'. Search did not include patents and citations embedded in documents

\begin{tabular}{|c|c|c|c|}
\hline \multirow[t]{2}{*}{ Reference } & \multirow[t]{2}{*}{ Contribution } & \multicolumn{2}{|c|}{ Cites } \\
\hline & & No. & Rank \\
\hline Camerano $(1880)^{\mathrm{a}}$ & First graphical depiction of food web & 41 & - \\
\hline Pierce et al. $(1912)^{a}$ & Graphical description of food web & 70 & - \\
\hline Shelford $(1913)^{\mathrm{a}}$ & Graphical description of food web & 410 & - \\
\hline Petersen $(1915)^{\mathrm{a}}$ & Graphical description of food web & 24 & - \\
\hline Summerhayes \& Elton (1923) & Description of the herring food web & 171 & - \\
\hline Hardy (1924) & Description of the herring food web & 233 & - \\
\hline Thienemann $(1926)^{\mathrm{a}}$ & $\begin{array}{l}\text { Nutrient cycles and lake food webs; introduced to limnology the terms } \\
\text { 'producers','consumers', and 'reducers' }\end{array}$ & 66 & - \\
\hline Elton (1927) & $\begin{array}{l}\text { Pioneer of ecology, analysed ecosystems by pyramids of numbers at } \\
\text { different trophic levels }\end{array}$ & 2309 & 9 \\
\hline Lindeman (1942) & Introduction of the trophodynamics concept & 2422 & 8 \\
\hline Hairston et al. (1960) & $\begin{array}{l}\text { Ecosystem description simplified as plant, herbivore and carnivore } \\
\text { trophic levels }\end{array}$ & 2481 & 6 \\
\hline Paine (1966) & Importance of predation in shaping the intertidal rocky shore community & 3904 & 3 \\
\hline Odum (1969) & $\begin{array}{l}\text { Definition of measures, also related to food webs, for assessing the } \\
\text { development stage of an ecosystem }\end{array}$ & 4316 & 2 \\
\hline Ryther (1969) & $\begin{array}{l}\text { Food chain dynamics and primary productivity as main drivers of fish } \\
\text { production }\end{array}$ & 1338 & 17 \\
\hline Odum et al. (1971) & Food webs as central in ecology for a holistic view of ecosystems & 9846 & 1 \\
\hline Vollenweider (1971) & Eutrophication affecting food chain in lakes & 1605 & 12 \\
\hline Pomeroy (1974) & $\begin{array}{l}\text { Changing the paradigm of linear food chain to complex food webs in } \\
\text { the ocean }\end{array}$ & 1052 & 23 \\
\hline Menge \& Sutherland (1976) & Crucial role of predation in shaping the structure of communities & 930 & 26 \\
\hline Price et al. (1980) & Trophic interactions in terrestrial ecosystems & 1746 & 11 \\
\hline Paine (1980) & Importance of food web interaction strength in shaping community structure & 1343 & 16 \\
\hline Oksanen et al. (1981) & Holistic vision of ecosystems and the effects of exploitation on food webs & 1261 & 19 \\
\hline Pimm (1982) & Fundamental theory and analysis of food webs & 1462 & 14 \\
\hline Landry \& Hassett (1982) & Trophic role of microzooplankton in marine food webs & 851 & 29 \\
\hline Azam et al. (1983) & Role of bacteria in the biogeochemical food webs of marine systems & 3820 & 4 \\
\hline Minagawa \& Wada (1984) & Nitrogen isotopic fractionation per feeding passage is independent of habitat & 2447 & 7 \\
\hline Pimm (1984) & Relationship between complexity and stability through food web indicators & 1506 & 13 \\
\hline Schoeninger \& DeNiro (1984) & $\begin{array}{l}\text { Stable isotope data for marine and terrestrial organisms highlight food } \\
\text { web relationships }\end{array}$ & 923 & 27 \\
\hline Carpenter et al. (1985) & $\begin{array}{l}\text { Trophic interaction allows ecosystem changes to cascade through the } \\
\text { food webs }\end{array}$ & 2028 & 10 \\
\hline Odum (1985) & $\begin{array}{l}\text { Responses of ecosystems to stress, including effects on structure, matter } \\
\text { cycling and energy flows }\end{array}$ & 890 & 28 \\
\hline Menge \& Sutherland (1987) & $\begin{array}{l}\text { Trophic structure of communities depending on environmental factors, } \\
\text { competition and predation }\end{array}$ & 1093 & 22 \\
\hline May (1988) & Comparing food web structure to highlight common patterns in food webs & 1132 & 21 \\
\hline Polis et al. (1989) & Importance of including cannibalism and intraguild predation in food webs & 1298 & 18 \\
\hline Decho (1990) & $\begin{array}{l}\text { Polymers excreted by microbial organisms have an important role for } \\
\text { lower marine food webs }\end{array}$ & 1030 & 24 \\
\hline Polis \& Strong (1996) & Central role of omnivory in food web dynamics & 1363 & 15 \\
\hline Polis et al. (1997) & Importance of spatial processes for food web structure and dynamics & 1172 & 20 \\
\hline Pauly et al. (1998) & Use of trophic level to assess the effects of fishing on marine communities & 3318 & 5 \\
\hline Williams \& Martinez (2000) & Properties of niche model are very similar to true food webs & 843 & 30 \\
\hline $\begin{array}{l}\text { Vander Zanden \& Rasmussen } \\
\text { (2001) }\end{array}$ & Stable isotopes for delineating trophic interactions and trophic levels & 952 & 25 \\
\hline 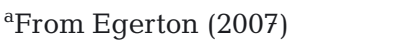 & & & \\
\hline
\end{tabular}


Fig. 1. Frequency of trophodynamic terms in the literature. Ngram: searches in the corpus of digitized books extracted using the Ngram Google (http:// books.google.com/ngrams) for level+ Trophic level+trophic levels+Trophic levels, food web+food webs+Food web+Food webs and food chain+food chains+Food chain+Food chains (percentage of a phrase appearing in the books, compared to the total all phrases having the same number of words). Scopus: proportion of articles indexed in Scopus (www.scopus.com) containing 'food web(s)' in the title, abstract or keywords (percentage of all papers indexed); search conduct on 12 August 2014

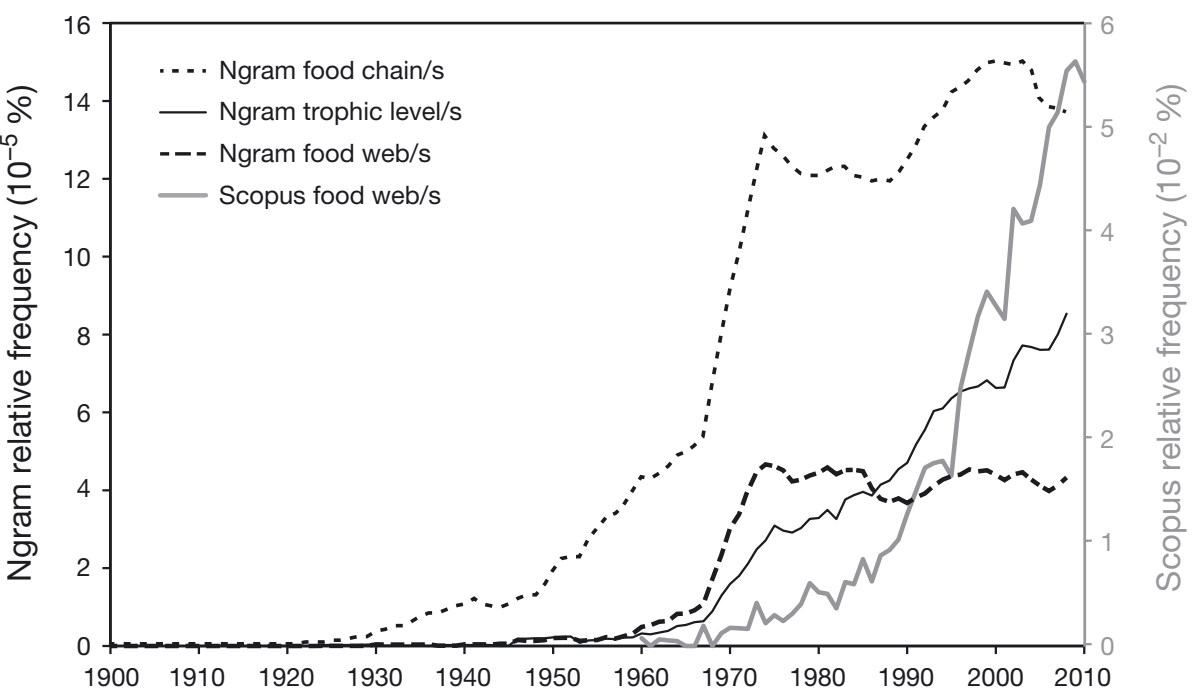

levels, trophic level itself has been used as an index of perturbation, particularly in aquatic ecosystems, debates on the efficiency of energy transfer across trophic levels have arisen, and trophodynamic models have become widely available. These advances have led to the definition of ecosystem health indicators (Ulanowicz 1986, Costanza \& Mageau 1999), and ultimately to the setting of reference points for ecosystem-based management.

\section{TOPICS IN THIS THEME SECTION (TS)}

We invited marine ecologists to submit papers on general patterns and processes of trophodynamics in marine ecosystems, combining theoretical, empirical, experimental and comparative studies that address (1) novel approaches to trophodynamics in marine ecosystems, (2) common properties of marine food webs, and (3) trophodynamics as a basis for management.

\section{Novel approaches}

Trophodynamics elucidates who eats whom, a difficult task in marine systems. Stomach content analysis in aquatic vertebrates has been the main method used for a long time, but the method has restricted spatio-temporal resolution (e.g. Paine 1988). In addition, it is complicated by digestibility of prey, and the abundance of unidentifiable material makes quantification of prey difficult (Pinnegar \& Polunin 1999). $\mathrm{N}$ and $\mathrm{C}$ stable isotope analysis (Minagawa \& Wada 1984) is now extensively used for the identification of food web pathways (Vander Zanden \& Rasmussen define trophic relationships among and across trophic 
1999). However, unequivocal quantification of food linkages is especially difficult in the case of omnivory, which is common in marine systems (Pimm et al. 1991). The use of the isotopic method needs to move beyond integrating or averaging feeding habits over longer time scales, and additional analysis methods are needed for determining food preferences.

In this TS, Soares et al. (2014) and Corbisier et al. (2014) exemplify the state of the art in the use of the stable isotopes to delineate ecosystem processes off the Brazilian coast. Both studies explore the application of the isotope method for disentangling ecosystem functions such as biophysical processes related to upwelling and bentho-pelagic coupling. Other tracers can also be used for the determination of trophodynamic linkages: Pethybridge et al. (2014) analysed the fingerprint of fatty acids for small pelagics and their planktonic prey in the NW Mediterranean, showing the strong potential of this method for delineating food preferences. Conversely, Muto et al. (2014) showed that mercury biomagnification can be used to trace trophic positions in species of the northern Brazilian continental shelf. As an example of how to integrate such information, Prato et al. (2014) built a food web model of the NW Mediterranean using field-derived information. They show the effects of biological articulation on food web indicators and identify taxa of little commercial interest but high trophodynamic importance.

\section{Ecosystem indicators}

A number of indicators derived from key food web features have been proposed to describe ecosystems (e.g. Pimm et al. 1991: structure properties of webs; Pauly \& Christensen 1995: food web flows; Ulanowicz 1986, Link 2002: food web network analyses). Although some of these indicators worked better for theoretical insights (De Angelis 1975, May 1988) and others were applied towards ecosystem assessment (Costanza \& Mageau 1999), there is no clear border between the two (Rossberg 2013). Within this context, one reliable approach to better understand the functioning of marine ecosystems and to identify key indícators is inter-ecosystem comparison of food web properties (sensu Murawski et al. 2010). Ecosystem indicators must be tested before they are used for assessing the impacts of natural and anthropogenic change. More than 70 years after Lindeman, the use of transfer efficiency as an indicator continues to be an interesting topic. The fact that old and new indi- cators are not fully tested, however, should not be seen as a limit for their application. Some papers in this TS show the potential of these applications and comparisons.

In this TS, Jordán et al. (2014) measured asymmetrical trophic relationships in a food web to identify key species for ecosystem management. Plagányi et al. (2014) used a multispecies food web model to define indicators of ecosystem shifts. Shannon et al. (2014a) used trophic level based indicators derived from models and catch data to detect structural changes induced by fisheries. Niquil et al. (2014) tested 4 metrics - food chain length, detritivory/herbivory ratio, average transfer efficiency, and transfer efficiency by TL - by comparing 6 models of estuarine ecosystems at different degrees of disturbance. Finally, using trophic relationships and biomass data from Ecopath models, combined in Ecospace with primary production and habitat preferences for the world oceans, Christensen et al. (2014) obtained a worldwide spatial distribution of fish biomass over more than a century, showing the large decline of fish biomass, in particular of top predators.

\section{Management}

Complex evolutionary and ecological interactions emerge only if species are studied in the context of food webs, and not in isolation (Cohen et al. 1993), but only on few occasions has this approach been used to quantify impacts of human activities and to address management strategies (Pauly et al. 1998, Plaganyi 2007, Fulton et al. 2011). The uncertainty associated with the trophodynamic approach is often considered an important limitation (Hilborn 2011), but in multi-species fisheries, food web information can account for indirect (e.g. compensatory) effects ('tradeoffs' in Link 2010). Insights derived from trophodynamic analysis have provided context for single species fishery management (Tyrrell et al. 2011), and their use shows promise. In this TS, some contributions provide evidence in favor of the use of trophodynamics for management purposes (cf. ICES 2014).

Morello et al. (2014) explored food web Models of Intermediate Complexity for Ecosystem assessments (MICE) that demonstrated how measures based on trophic interactions can control outbreaks of the crown-of-thorns starfish. Kleisner et al. (2014) correct the mean trophic level of fisheries catches by considering a fishery's geographic expansion; corrected catches confirm the fishing down the food web (Pauly 
et al. 1998) phenomenon. Analyzing the pattern of biomass accumulation across trophic levels, Pranovi et al. (2014) develop a new method to assess ecosystem changes after major perturbations; from a theoretical point of view, a perturbed ecosystem should lower the stored, cumulative biomass and 'stretch out' across TLs (Pranovi et al. 2014). Shannon et al. (2014b) analyzed the outputs of 5 ecosystem models for the southern Benguela Current to communicate with stakeholders and reach consensus on management decisions.

\section{DISCUSSION}

\section{Quantifying trophodynamics is not easy}

Current field data mainly include biomass of fishes and large invertebrates, some growth and turnover rates, and some fish food habits. These data are used for the construction of conceptual food web and ecosystem models, i.e. we build ecosystem descriptions using reductionist pieces. Thus, 70 years after Lindeman, we are still building the large picture by compiling pixels here and there, usually referring to a species that we target and eat. What can be done in the near term? (1) Metadata collections that facilitate integration and comparison of available information such as FishBase (www. fishbase.org, Froese \& Pauly 2014) for fish and SeaLifeBase (www.sealifebase.org, Palomares \& Pauly 2014) for non-fish marine taxa, should receive routine support. (2) Community ecologists must collect field measures with key trophodynamic information (e.g. efficiencies and rates) on crucial components (e.g. key species). Preliminary food web analyses can help to identify key factors that can be determined at low cost.

This TS shows the usefulness of isotopic enrichment, lipid fingerprints and contaminants in providing trophodynamic information. Other methods, such as molecular and genetic approaches, should also be more broadly considered for informing. We are far from having a trophodynamics tool similar to the satellite information on ocean primary production; ideally, we should have continuous, comprehensive and synoptic information on all trophic levels higher than TL 1. Sensitivity and uncertainty analysis (e.g. Pranovi et al. 2014, Prato et al. 2014) can test the robustness of trophodynamic models and identify key ecosystem elements (food web nodes, aggregation level; e.g. Jordán et al. 2014) on which data collection needs to focus.

\section{A gap between theory and reality}

Although there is asymmetry in trophic interactions, (something we do not fully understand), food web descriptions are often based on steady state assumptions in trophic flows and transfer efficiencies; since these are difficult to determine in the field, analyses are usually based on rates estimated from empirical formulas (e.g. consumption per unit of biomass; Palomares \& Pauly 1998) or extrapolated from other models. This does not always allow us to discriminate between artefacts and real patterns.

We need more detailed analyses of productivity, transfer efficiencies, and flux measures at all trophic levels (Niquil et al. 2014). Additionally, novel and simple ways to quantitatively represent the marine food web should be developed; this can be achieved by losing taxonomic resolution, but may provide better assessments of system energy flow. Comparative studies across ecosystems are required for evaluating trophodynamic theory, identifying common patterns as well as differences, and suggesting ecosystem indicators.

\section{Use of trophodynamics for management}

Fisheries regulation, pollution abatement, pest control and other management activities benefit from trophodynamic inputs, as required by Europe's Marine Strategy Framework Directive (EU 2008; cf. ICES 2014) for defining the environmental status of marine ecosystems. Trophodynamics can provide a strategic framework for embedding traditional approaches such as single species targets. The various ecosystem aspects (e.g. structure, function, resilience, stability) require a set of indicators for applications in management (ICES 2014). Indicators that have been extensively tested, (e.g. mean trophic level of catch: Pauly et al. 1998; primary production required: Pauly \& Christensen 1995), are the most promising. However, there will always be a need for new indicators that might perform better in terms of sensitivity to environmental change, accuracy, simplicity of monitoring and ease of comprehension (e.g. Coll et al. 2008, Libralato et al. 2008, Pranovi et al. 2014).

\section{Perspectives}

This TS includes contributions on marine trophodynamics that (1) provide an exemplary view of the state of the art, (2) provide evidence on current 
limits, advantages and potential of trophodynamic measures, and (3) stimulate discussion across marine and terrestrial facets of trophodynamics research. This TS also shows that ideas continue to grow from the seminal work of Lindeman (1942), with the recent extension to marine ecosystems. Despite controversies, uncertainties and information gaps, trophodynamics as an organizing theme is robust and valuable for marine ecological research. Although trophodynamics concepts and methods are not fully operational in terms of marine ecosystem management, this TS exemplifies that trophodynamics remains a useful area for both theoretical and applied research.

\section{LITERATURE CITED}

Azam F, Fenchel T, Field JG, Gray JS, Meyer-Reil LA, Thingstad F (1983) The ecological role of water-column microbes in the sea. Mar Ecol Prog Ser 10:257-263

Baird D, Ulanowicz RE (1989) The seasonal dynamics of the Chesapeake Bay ecosystem. Ecol Monogr 59:329-364

Camerano L (1880) Dell' equilibrio dei viventi mercè la reciproca distruzione. Att Real Acc Sci Torino 15:393-414

> Carpenter SR, Kitchell JF, Hodgson JR (1985) Cascading trophic interactions and lake productivity. Bioscience 35 : 634-639

Christensen V, Pauly D (1990) A draft guide to the ECOPATH II program (ver. 1.0). ICLARM Software 6, ICLARM, Manila

Christensen V, Coll M, Piroddi C, Steenbeek J, Buszowski J, Pauly D (2014) A century of fish biomass decline in the ocean. Mar Ecol Prog Ser 512:155-166

> Clarke GL (1946) Dynamics of production in aquatic populations. Ecol Monogr 16:321-335

Cohen JE, Bearer RA, Cousins SH, De Angelis DL and others (1993) Improving food webs. Ecology 74:252-258

Coll M, Libralato S, Tudela S, Palomera I, Pranovi F (2008) Ecosystem overfishing in the ocean. PLoS ONE 3:e3881

> Corbisier TN, Petti MAV, Soares LSH, Muto EY, Bromberg S, Valiela I (2014) Trophic structure of benthic communities in the Cabo Frio upwelling system (southeastern Brazilian shelf): a temporal study using stable isotope analysis. Mar Ecol Prog Ser 512:23-38

> Costanza R, Mageau M (1999) What is a healthy ecosystem? Aquat Ecol 33:105-115

$>$ De Angelis DL (1975) Stability and connectance in food web models. Ecology 56:238-243

Decho AW (1990) Microbial exopolymer secretions in ocean environments: their role(s) in food webs and marine processes. Oceanogr Mar Biol Annu Rev 28:73-153

EU (European Union) (2008) Directive 2008/56/EC of the European Parliament and of the Council of 17 June 2008 establishing a framework for community action in the field of marine environmental policy (Marine Strategy Framework Directive). Offic J Eur Union L164: $19-40$

Egerton FN (2007) Understanding food chains and food webs 1700-1970. Bull Ecol Soc Am 88:50-69

Elton CS (1927) Animal ecology. Sidgwick \& Jackson, London

Froese R, Pauly D (2014) FishBase. www.fishbase.org, version $(06 / 2014)$
Fulton EA, Link JS, Kaplan I, Savina-Rolland M and others (2011) Lessons in modelling and management of marine ecosystems: the Atlantis experience. Fish Fish 12:171-188

> Hairston NG, Smith FE, Slobodkin LB (1960) Community structure, population control, and competition. Am Nat 94:421-425

Hardy AC (1924) The herring in relation to its animate environment. 1. The food and feeding habits of the herring with special reference to the east coast of England. Fish Invest London Ser II 7:1-53

Hilborn R (2011) Future directions in ecosystem based fisheries management: a personal perspective. Fish Res 108: 235-239

ICES (International Council for the Exploration of the Sea) (2014) Report of the workshop to develop recommendations for potentially useful Food Web Indicators (WKFooWI). ICES CM 2014\ACOM:48

Jordán F, Scotti M, Mike Á, Ortiz M (2014) Strong asymmetrical inter-specific relationships in food web simulations. Mar Ecol Prog Ser 512:89-98

Kleisner K, Mansour H, Pauly D (2014) Region-based MTI: resolving geographic expansion in the Marine Trophic Index. Mar Ecol Prog Ser 512:185-199

Landry MR, Hassett RP (1982) Estimating the grazing impact of marine micro-zooplankton. Mar Biol 67:283-288

Libralato S, Coll M, Tudela S, Palomera I, Pranovi F (2008) Novel index for quantification of ecosystem effects of fishing as removal of secondary production. Mar Ecol Prog Ser 355:107-129

> Lindeman RL (1942) The trophic-dynamic aspect of ecology. Ecology 23:399-417

> Link JS (2002) Does food web theory work for marine ecosystems? Mar Ecol Prog Ser 230:1-9

Link JS (2010) Ecosystem-based fisheries management: confronting tradeoffs. Cambridge University Press, New York, NY

Mann KH (1969) The dynamics of aquatic ecosystems. Academic Press, New York, NY

May RM (1988) How many species are there on Earth? Science 247:1441-1449

Menge BA, Sutherland JP (1976) Species diversity gradients: synthesis of the roles of predation, competition, and temporal heterogeneity. Am Nat 110:351-369

- Minagawa M, Wada E (1984) Stepwise enrichment of ${ }^{15} \mathrm{~N}$ along food chains: further evidence and the relation between $\delta^{15} \mathrm{~N}$ and animal age. Geochim Cosmochim Acta 48:1135-1140

Morello EB, Plagányi ÉE, Babcock RC, Sweatman H, Hillary R, Punt AE (2014) Model to manage and reduce crown-ofthorns starfish outbreaks. Mar Ecol Prog Ser 512:167-183

> Murawski SA, Steele JH, Taylor P, Fogarty MJ, Sissenwine MP, Ford M, Suchman C (2010) Why compare marine ecosystems? ICES J Mar Sci 67:1-9

Muto EY, Soares LSH, Sarkis JES, Hortellani MA, Petti MAV, Corbisier TN (2014) Biomagnification of mercury through the food web of the Santos continental shelf, subtropical Brazil. Mar Ecol Prog Ser 512:55-70

> Niquil N, Baeta A, Marques JC, Chaalali A, Lobry J, Patrício J (2014) Reaction of an estuarine food web to disturbance: applying Lindeman's perspective. Mar Ecol Prog Ser 512:141-154

> Odum EP (1969) The strategy of ecosystem development. Science 164:262-270

Odum EP (1985) Trends expected in stressed ecosystems. Bioscience 35:419-422 
Odum EP, Odum HT, Andrews J (1971) Fundamentals of ecology. Saunders, Philadelphia, PA

> Oksanen L, Fretwell SD, Arruda J, Niemela P (1981) Exploitation ecosystems in gradients of primary productivity. Am Nat 118:240-261

Paine RT (1966) Food web complexity and species diversity. Am Nat 100:65-75

Paine RT (1980) Food webs: linkage, interaction strength and community infrastructure. J Anim Ecol 49:667-685

Paine RT (1988) Food webs: road maps of interactions or grist for theoretical development? Ecology 69:1648-1654

Palomares MLD, Pauly D (1998) Predicting food consumption of fish populations as functions of mortality, food type, morphometrics, temperature and salinity. Mar Freshw Res 49:447-453

Palomares MLD, Pauly D (2014) SeaLifeBase. www.sealifebase.org, version $(06 / 2014)$

Pauly D, Christensen V (1995) Primary production required to sustain global fisheries. Nature 374:255-257

Pauly D, Christensen V, Dalsgaard J, Froese R, Torres F Jr (1998) Fishing down marine food webs. Science 279: 860-863

Pethybridge $\mathrm{H}$, Bodin N, Arsenault-Pernet EJ, Bourdeix JH and others (2014) Temporal and inter-specific variations in forage fish feeding conditions in the NW Mediterranean: lipid content and fatty acid compositional changes. Mar Ecol Prog Ser 512:39-54

Pimm SL (1982) Food webs. Chapman \& Hall, London

Pimm SL (1984) The complexity and stability of ecosystems. Nature 307:321-326

Pimm SL, Lawton JH, Cohen JE (1991) Food web patterns and their consequences. Nature 350:669-674

- Pinnegar JK, Polunin NVC (1999) Differential fractionation of $\delta^{13} \mathrm{C}$ and $\delta^{15} \mathrm{~N}$ among fish tissue: implication for the study of trophic interactions. Funct Ecol 13:225-231

Plagányi ÉE (2007) Models for an ecosystem approach to fisheries. Fish Tech Pap 477, FAO, Rome

Plagányi ÉE, Ellis N, Blamey LK, Morello EB and others (2014) Ecosystem modelling provides clues to understanding ecological tipping points. Mar Ecol Prog Ser 512:99-113

Polis GA, Strong DR (1996) Food web complexity and community dynamic. Am Nat 147:813-846

Polis GA, Myers CA, Holt RD (1989) The ecology and evolution of intraguild predation. Annu Rev Ecol Syst 20: 297-330

Polis GA, Anderson WB, Holt RD (1997) Toward an integration of landscape ecology and food web ecology: the dynamics of spatially subsidized food webs. Annu Rev Ecol Syst 28:289-316

Submitted: September 9, 2014; Accepted: September 10, 2014
Polovina JJ, Ow MD (1983). ECOPATH: a user's manual and program listings. NOAA, National Marine Fisheries Service, Honolulu Admin Rep 23, Honolulu

Pomeroy LR (1974) The ocean's food web: a changing paradigm. Bioscience 24:499-504

Pranovi F, Libralato S, Zucchetta M, Link JS (2014) Biomass accumulation across trophic levels: analysis of landings for the Mediterranean Sea. Mar Ecol Prog Ser 512: 201-216

Prato G, Gascuel D, Valls A, Francour P (2014) Balancing complexity and feasibility in Mediterranean coastal foodweb models: uncertainty and constraints. Mar Ecol Prog Ser 512:71-88

Price PW, Bouton CE, Gross P, McPheron BA, Thompson JN, Weis AE (1980) Interactions among three trophic levels: influence of plants on interactions between insect herbivores and natural enemies. Annu Rev Ecol Syst 11:41-65

Rossberg A (2013) Food webs and biodiversity: foundations, models, data. Wiley, Chichester

> Ryther JH (1969) Photosynthesis and fish production in the sea. Science 166:72-76

> Shannon L, Coll M, Bundy A, Gascuel D and others (2014a) Trophic level-based indicators to track fishing impacts across marine ecosystems. Mar Ecol Prog Ser 512: $115-140$

Shannon LJ, Osman W, Jarre A (2014b) Communicating changes in state of the southern Benguela ecosystem using trophic, model-derived indicators. Mar Ecol Prog Ser 512:217-237

> Soares LSH, Muto EY, Lopez JP, Clauzet GRV, Valiela I (2014) Seasonal variability of $\delta^{13} \mathrm{C}$ and $\delta^{15} \mathrm{~N}$ of fish and squid in the Cabo Frio upwelling system of the southwestern Atlantic. Mar Ecol Prog Ser 512:9-21

Summerhayes VS, Elton CS (1923) Contributions to the ecology of Spitsbergen and Bear Island. J Ecol 11:214-286

Tyrrell MC, Link JS, Moustahfid H (2011) The importance of including predation in some fish population models: implications for biological reference points. Fish Res 108: $1-8$

Ulanowicz RE (1986) Growth and development: ecosystems phenomenology. Springer, New York, NY

Vander Zanden MJ, Rasmussen JB (1999) Primary consumer $\delta^{13} \mathrm{C}$ and $\delta^{15} \mathrm{~N}$ and the trophic position of aquatic consumers. Ecology 80:1395-1404

Vollenweider RA (1971) Scientific fundamentals of the eutrophication of lakes and flowing waters, with particular reference to nitrogen and phosphorus as factors in eutrophication. OECD, Paris

Williams RJ, Martinez ND (2000) Simple rules yield complex food webs. Nature 404:180-183

Proofs received from author(s): September 18, 2014 